\section{Recovery of antediluvian DNA}

SIR - The recovery of DNA from the tissue remains of extinct animals and its amplification by polymerase chain reaction (PCR) has recently generated much excitement and speculation. Unique information has been gained from mitochondrial DNA sequences of animals extinct for several thousand years, including the giant ground sloth, the moa bird, the sabre-toothed tiger and even the mammoth. Animals which vanished more recently, such as the quagga and the Tasmanian wolf, have also been investigated. The oldest DNA fragments amplified with certainty by PCR are 20,000-40,000 years of age. Beyond this point, time-dependent chemical decay of DNA structure makes successful retrieval difficult ${ }^{1}$. A careful investigation $^{2}$ of pyrolysis products of 20-million-year-old magnolia leaves by gas chromatography/mass spectrometry showed that complex macromolecules such as polysaccharides and proteins are completely decomposed, although some lignin remains. It is improbable that any DNA could survive in such material. Despite an initial claim $^{3}$, a detailed investigation also demonstrated that plant DNA could not be amplified from such leaves ${ }^{4}$.

Two independent reports have appeared on the apparent recovery of DNA, 20-120 million years old, from a single weevil ${ }^{5}$ and from a termite 6 entombed in amber. This is surprising, because it is unlikely that any DNA sequences could survive that long. Endogenous oxidative damage is one of the major threats to intracellular $\mathrm{DNA}^{7}$; 4,000-year-old DNA from dried and mummified tissue has already undergone substantial base oxidation ${ }^{8}$; and amber would not be expected to afford complete protection against oxygen. A major problem with attempts to retrieve very old DNA is the risk of contamination with traces of contemporary DNA. Thus,

1. Lindahl, T. Nature 362, 709-715 (1993)

2. Logan, G. A., Boon, J. J. \& Egtinton, B. Proc. natn. Acad Sci.U.S.A. 90, 2246-2250 (1993)

3. Golenberg. E. M. et al. Nature 344.656-658 (1990)

4. Sidow. A., Wilson, A. C.\& Pääbo, S. Phil. Trans. R. Soc. B333, 429-433 (1991)

5. Cano, R. J., Poinar, H. N., Pieniazek, N. J., Acra, A. \& Poinar, G. O. Jr Nature 363, 536-538 (1993)

6. De Salle, R., Gatesy, J., Wheeler, W. \& Grimaldi, D. Science 257. 1933-1936 (1992).

7. Richter, C., Park, J.-W. \& Ames, B. N. Proc. natn. Acad. Sci.U.S.A. 85, 6465-6467 (1988)

8. Pääbo, S., Irwin, D. M. \& Wilson, A. C. J. biol. Chem. 265 4718-4721 (1990).

9. Randerath, K., Leihr, J. G., Gladek, A. \& Randerath, E. Mut. Res. 219, 121-133 (1989)

10. Cano, R. J., Poinar, H. N., Roubik, D. \& Poinar, G. O. Jr Med. Sci. Res. 20,619-622 (1992).

11. Poinar, H. N.. Cano, R. J. \& Poinar, G. O. Jr Nature 363. 677 (1993).

12. Henwood, A. A. thesis, Univ. Cambridge (1992)
DNA might be obtained from pulverised fossil material from the Burgess shale after a sufficient number of PCR cycles, and the DNA might not be identical to any known sequence that has been deposited in data banks, but this does not prove that such DNA was of Cambrian rather than contemporary origin. Furthermore, it is hardly surprising that insectlike DNA can be detected by PCR in experiments carried out in a department of entomology.

The following simple controls should be performed in experiments of this type:

(1) Comparison of positive and negative data. Many attempts to retrieve very ancient DNA by PCR under carefully controlled conditions have been unsuccessful. Such information should be made generally available, for example through a computer bulletin board or the Ancient DNA Newsletter (care of Institute of Zoology, Regent's Park, London NW1 $4 \mathrm{RY}, \mathrm{UK}$ ), so that negative results can be compared with the occasional positive claims that are published in leading scientific journals.

(2) Reproducibility. Some species of amber-entombed insects have been found many times. It would greatly strengthen the case for credible recovery of very ancient DNA if three such specimens of an insect, collected from different amber deposits and PCR-amplified in different laboratories, were to yield the same DNA sequence.

(3) Negative controls. A piece of amber without an entombed insect, perhaps containing a fragment of wood or stone, should be extracted and PCR-amplified under the same conditions. The DNA amplified by PCR from such material should be compared with that from the insect in amber.

(4) Chemical analysis. The gas chromatography/mass spectrometry technique already used on fossil leaves ${ }^{2}$ should also be used with amber-entombed material. If no proteins or polysaccharides remain, no DNA will have survived either. Similarly, the extremely sensitive ${ }^{32} \mathrm{P}$ post-labelling technique, originally devised to detect minute amounts of damaged nucleotides in mammalian DNA after exposure to mutagens ${ }^{9}$, could be used to demonstrate the presence or absence of any traces of deoxyribonucleotide material. This method might also yield information on whether most DNA pyrimidines, if detected, would have been oxidised into non-coding ring-fragmented forms ( $N$-substituted urea), which could not be copied by a DNA polymerase during PCR.

Recent claims of recovery of 100 million-ycar-old DNA have overshadowed the valuable and important studies on moderately ancient DNA. Rather than proceed spectacularly further and further back in time with anecdotal reports on single samples, using the notoriously contamination-sensitive PCR technique, I suggest that the next goal be a convincing report on the amplification of small DNA fragments, say, 100,000 years old.

\section{Tomas Lindahl}

Imperial Cancer Research Fund,

Clare Hall Laboratories,

Blanche Lane,

\section{South Mimms,}

Hertfordshire EN6 3LD, UK

POINAR REPLIES - Lindahl mentions only two reports on the recovery of DNA from amber inclusions, one from a Tertiary termite $^{6}$ and the other from a Cretaceous weevil ${ }^{5}$. A thorough literature search would have revealed that the first successful extraction was that of a bee in Dominican amber ${ }^{10}$ and the most recent is that of a leaf in Dominican amber ${ }^{11}$.

His 'off the cuff' remark that "it is hardly surprising that insect-like DNA can be detected by PCR in experiments carried out in a department of entomology" shows only that his analysis of the literature is incomplete. In our experiments, none of the extraction, amplification or sequencing was conducted in a department of entomology, or of botany for that matter.

Furthermore, we investigated comparative extant forms only after completely sequencing the extinct species, and we ran more than 20 environmental controls with each PCR cycle. Moreover, experiments were conducted with the extant and extinct species in different places in the building. The controls suggested by Lindahl are quite acceptable and some (reproducibility and negative controls) have already been done for the bee in Dominican amber. Our group has isolated DNA from five separate specimens of Proplebeia dominicana and Rus Hoelzel, in independent experiments, has isolated DNA from the same bee species in Dominican amber (see ref. 12).

There are many types of fossilization processes, and to assume that the breakdown of DNA is similar in all of them, or is equivalent to that in non-fossilized material, is not scientific. In contrast to Lindahl's statement of the theoretical lifespan of DNA based on experimental data $^{1}$, amber maintains the integrity of this molecule for incredibly long periods. We still do not know what components in the resin are responsible for this remarkable degree of preservation, but the fact that DNA is still extractable after 120 million years opens the door much wider for a variety of evolutionary studies. The significance is far more than simply anecdotal.

\section{George 0. Poinar Jr}

Department of Entomological Science, University of California,

Berkeley, California 94720, USA 